\title{
Ontology, metaphysics and criticism as Transcendental Semantics as of Kant ${ }^{1}$
}

\author{
Ontologia, metafísica e crítica como \\ Semântica Transcendental a partir de Kant
}

Daniel Omar Perez*

Universidade Estadual de campinas (Unicamp), Campinas, SP, Brasil

\begin{abstract}
The aim of this paper is to present the core of Kant's critique of traditional metaphysics and ontology as a transcendental semantics that allows reformulating the problem about the objects and their reality. In order to achieve this purpose, we propound a paper divided in two parts: 1. A brief justification of Kant's semantics interpretation; 2. A work program based on a semantics comprehended as a fundamental part of a method of resolution of philosophical problems. Basically, we can state that the critical position against traditional metaphysics and ontology leads to the question upon: how are $a$ priori synthetic judgments possible? This question leads to its conditions of possibility,
\end{abstract}

1 Translation to English: Ana Carolina Meinerz.

* DOP: e-mail: danielomarperez1@gmail.com 
that is: sensible representations; intellectual representations; syntactic rules; semantic rules (or referential rules, on the relation between intellectual representations and some sort of sensibility or affection); the operator of the syntactic and semantic rules (subject, man, human nature, gender, people etc.). This is what we call the core of Kant's critique and with which we may begin to solve philosophical problems even beyond those presented by our philosopher. As such, we are briefly going to observe the following steps: 1. From metaphysics in its various senses to the ontology of sensible objects; 2 . A critique of pure reason against dogmatic metaphysics; 3 . Criticism as semantics; 4 . The semantic project and the kinds of judgments; 5 . Human nature and the theory of judgment; 6 . The work program within Kant's own work; 7. Subsequent results of Kant's project.

Keywords: Kant. Semantics. Ontology. Metaphysics. Criticismo. Transcendental.

\section{Resumo}

O objetivo deste texto é apresentar o núcleo da crítica kantiana à metafísica e à ontologia tradicionais como uma semântica transcendental que permite reformular o problema acerca dos objetos e da sua realidade. Para alcançar tal fim propomos uma comunicação em duas partes: 1. Uma breve justificação da interpretação semântica de Kant; 2. Um programa de trabalho a partir de uma semântica entendida como parte fundamental de um modo de resolução de problemas filosóficos. Basicamente, podemos dizer que a posição crítica contra a metafísica e a ontologia tradicionais leva à questão acerca de: como são possíveis os juízos sintéticos a priori? Esta pergunta conduz às suas condições de possibilidade, isto é: representações sensíveis; representações intelectuais; regras sintáticas; regras semânticas (ou referenciais, de relação entre as representações intelectuais e algum tipo de sensibilidade ou afetividade); o operador das regras sintáticas e semânticas (sujeito, homem, natureza humana, gênero, povo, etc). Isto constitui o que chamamos o núcleo da crítica em Kant e com o qual podemos começar a resolver os problemas filosóficos inclusive para além dos apresentados por nosso filósofo. Nesse sentido, seguiremos sumariamente os seguintes passos: 1. Da metafísica em seus vários sentidos à ontologia dos objetos sensíveis; 2 . Uma critica da razão pura contra a metafísica dogmática; 3. Critica como semântica; 4. O projeto semântico e os tipos de juízos; 5. A natureza humana e a teoria do juízo; 6 . O programa de trabalho dentro da própria obra de Kant; 7. Os resultados subsequentes do projeto de Kant.

Palavras-chave: Kant. Semântica. Ontologia. Metafísica. Crítica. Transcendental. 
It will be good for metaphysics not to take concepts for things or even their names for concepts therefore reasoning entirely on emptiness.

Kant.

\section{Introduction}

\section{From metaphysics in its various senses to the ontology of sensible objects}

Within Kant's work, we find different ways of defining the concepts of metaphysics and ontology. Some of these definitions refer to the work of dogmatic tradition in the history of philosophy, others report to a new meaning given in-relation-to or from-the critical work and transcendental philosophy ${ }^{2}$. In the specific case of the concept of metaphysics already stated in the pre-critical period, Kant says in Geistersehers erläutert durch Träume der Metaphysik (Dreams of a visionary) that this subject offers two types of benefits:

The first is to carry out tasks which raises the inquiring mind when comes to discover through reason hidden properties of things. However, on this matter, the result much disappoints hope and has escaped our eager hands.

Ter frustra compressa manus, effugit imago,

Par levibus ventis volucrique simílima somno ${ }^{3}$.

The other advantage comes more appropriate to the nature of human understanding and it is to prove whether the task is proportionate to what can be known or not, and the relation between this matter and the concepts of experience upon which all our judgments must always be

2 There are many works consulted during preparation of this research. We mention the most relevant for our reflection. Laywine, A (1993) Kant's early metaphysics and the origins of the critical philosophy. Volume 3 NAKs. California: Ridgeview Publishing Company. Daval, R (1951) La métaphysique de Kant. Perspectives sur la métaphysique de Kant d'après la théorie du schématisme. Paris: Presses Universitaries de France. Freuler, L (1992) Kant et la métaphysique spéculative. Paris: Vrin.

3 Translation: For three times his image moves vainly through his hands as a subtle wind like a fleeting dream. Virgil Aeneid II 793-794 and 701-702 Vl.

Rev. Filos., Aurora, Curitiba, v. 28, n. 44, p. 459-488, maio/ago. 2016 
supported. In this sense, metaphysics is a science of the limits of human reason ... (A 115)

Indeed, the "two advantages" Kant mentions in 1766 are nothing but only two perspectives under which we may comprehend metaphysics as what has so far resulted and as a task:

1) As an inquiry beyond the experience, Kant's disappointment relates to the concept of soul proposed by Swedenborg and analyzed in that text;

2) As a science of the boundaries.

One concerns the tradition's frustrating exercise (because it is never decisive) which seeks the hidden, the other indicates a task to be done and it is characterized as having a negative consequence. On the one hand, according to the 1766 text's results, dogmatic assertions about the concept of soul donnot resist through the analysis of its supposed validity in different contexts of use. Kant comes to the conclusion that we can not apply this category in any cognitive situation ${ }^{5}$. On the other hand, the task of knowing how far we can progress with the use of the understanding in the expansion of knowledge would not provide new knowledge, but it would avoid the illusion of seeking or stating what is beyond our limits. The problem of stating this or that positive knowledge about something shifts to an earlier point and leads off to take into account the conditions upon which this or that knowledge may be pronounced.

Yet in the full 1790s, once entirelly developed the horizon of critical philosophy, in the beginning of the manuscript on Welche wirklichen Fortschritte sind die, die Metaphysik und seit Leibnizens Wolffs Zeiten in

4 We have used two translations as references for the reading and interpretation of the text in german, one in spanish and the other one in portuguese. However, the translation used in the text was done by us.

5 I held an analysis of the procedure of this text in Perez, D. 0. (2008, 92 e ss.) Kant e o problema da significação. Curitiba: Champagnat, (2009) A Loucura como questão Semântica: Uma Interpretação Kantiana. Trans/Form/Ação, São Paulo, v. 32, n. 1, p. 95-117. 
Deustschland gemacht hat? (Progress of Metaphysics) ${ }^{6}$, Kant begins by stating that metaphysics is "a sea without shore where progress leaves no marks" (Kant Ak XX, 259). However, he also questions as follows: "What is exactly that reason seeks out of metaphysics? What ultimate purpose (Endzweck) does it have with its formulation? "(Kant XX Ak, 259). Thus, metaphysics would be "the science that purposes the progress of the sensible knowledge to the supersensible through reason "(Kant XX Ak, 260; italics added by us). The sensible knowledge would concern to the objects of the sensibility, which are studied by the sciences of possible experiences; and the supersensible would reach a kind of knowledge that does not concern to those kinds of experiences. Within this framework, Kant operates a reduction or a delimitaton of the meaning of ontology that Christian Wolff (2005) considered to be the prime philosophy. Against it, I quote Kant, namely:

Ontology is that science (as part of metaphysics) which constitutes a system of all concepts and principles of understanding, but only to the extent that refers to objects that can be given to the sensibility and be certified by the experience. Ontology does not touch the supersensible, ultimate purpose, however, of the metaphysics, thus does not belong to this last one but as propaedeutics, as porch or atrium of the mataphysics itself and it is called transcendental philosophy for it contains the conditions and first elements of all our a priori knowledge. In it there has not been much progress since Aristotle (Kant XX Ak, 260; italics added by us).

Any excess in the attribution of coverage of the presented concepts must be avoided while reading this paragraph. First, the phrase "all our a priori knowledge" refers only to all our a priori knowledge regarding the objects of cognitive experience, as we may specify from what is said at the beginning of the quote. This means that this definition of ontology reaches less the being qua being (either aristotelian or wolffian)

6 For an in-depth study of the concept of metaphysics in the Progress there is a work by Mario Caimi (1989) La metafisica de Kant. Reconstrucción de la argumentation del escrito de Kant. Los progresos de la metafísica desde lá época de Leibnizy de Wolff. Buenos Aires: Eudeba Publisher. There is salso a work by Feliz, Duke (1987) Estudio Preliminar. IN Kant, I. (1987) Los progresos de la metafísicas desde Leibniz y Wolff. Madrid: Tecnos Editorial. 
that the objects of a possible experience defined and delimited only in the first critique. Thus, Kant states that "ontology is a resolution of knowledge in a priori concepts of the understanding and has its use in experience" (Kant Ak XX, 260). Therefore, we must warn that, in this case, we are not speaking of the practical philosophy's objects. Still, a controversial point would be whether this definition of ontology includes the objects of mathematics or knowledge by framing of concepts, or not. We understand that although at times the excerptions may be ambiguous, implying that it comes to given objects, it is pertinent to state that it refers to sensible objects both pure and empirical. Therefore, it would effectively include objects like numbers or geometrical figures and also physical objects.

In turn, and secondly, a relation of equivalence between ontology and transcendental philosophy is settled. Hence, we have yet another issue that is neither trivial nor unproblematic: the writing of the 1790s reduces "transcendental philosophy" to an "ontology" and this one to the "science of the concepts and principles that refers to objects that can be given to the sensibility". We believe that along the development of GMS (Grounds) and KPV (The Critique of Practical Reason) there is another meaning of the wording "transcendental philosophy" that includes not only "the science of the concepts and principles that refers to objects that can be given to the sensibility" but also "the investigation about the supreme principle of morality", whereas a special kind of knowledge extends only to the principles of pure reason, with nothing empirical. But Kant, controversially, did not include this point in the text of Fortschritte (Progress).

In order to make our position explicit we can say that we perceive that Kant begins with a restricted notion of transcendental philosophy in the first critique connected to ontology explicated in the theoretical reason, and later he develops the concept of extended transcendental philosophy including the supreme principle of morality explicated in the practical reason. This movement will be comprehended in Fortschritte (Progress) by Kant as the transition from ontology to metaphysics, as reframed concepts and, wherefore, differed from the 
meaning of the those ones used in the tradition characterized by Kant as dogmatic.

\section{A critique of pure reason against dogmatic metaphysics}

According to Kant in Fortschritte (Progress), metaphysics "in its scholastic concept is the system of all the principles of pure theoretical rational knowledge through concepts, in short: it is the system of pure theoretical philosophy" (Kant XX Ak, 261). Thus, the dogmatic metaphysical thinkers went forward with ontological principles beyond the objects of experience where nothing can be confirmed or refuted, that is, said as valid, precisely because it's no longer about the sensible, but the supersensible. "This is the way of the dogmatics, previous to Plato and Aristotle, but extendable to Leibniz and Wolff ..." (Kant Ak XX, 262). This natural and illusory way of the operation of reason itself finds, in contrast, the skeptics'way with its doctrine of doubt about the dogmatic assertions. The third step taken by metaphysics is held in the Critique of Pure Reason in terms of the capacity (Vermögen) of $a$ priori expansion of human knowledge in general. According to Kant, the three times (dogmatism, skepticism and criticism) are based on the very nature of the human capacity of knowledge in its operation. This means that it is not a continuous line of absolute overcome, but three times that can always restart according to the way reason operates.

In order to move forward on a comment of the "progress of metaphysics" and understand the nature of a critique of pure reason, we shall divide the question into a formal section and a material section. The formal part that concerns us for the purpose of observing the progress of reason in trying to solve its necessary problems is divided by Kant into three steps:

1) To make the distinction between analytic judgments and synthetic one;

2) To formulate the question: how are a priori synthetic judgments possible?; 
3) To establish the problem of the possibility of a priori synthetic judgments: this is, to discuss its possibility and to prove its objective reality.

In this third point, about the possibility (validity) and evidence, we find the indispensable syntactic and semantic elements we shall highlight. Only with the deployment of that route, which is concluded by the presentation of the elements for an evidence, within a critique of pure reason, we will be able to retake the problem of the possibility of a metaphysics along Kant:

The transcendental philosophy, that is, the doctrine upon the possibility of all a priori knowledge in general, which is the critique of pure reason and whose elements have been now fully presented, has as its aim the establishment of a metaphysics, whose purpose, for its turn, while purpose of pure reason, propones itself to extend the bound of the sensible to the supersensible; and this is an over step (Überschritt), which in order not to be a dangerous shift, once it is not a continuous process within the same order of principles, an extreme concern is required related to the boundaries of both territories (Kant, AK XX, 272).

At the same time, it is deterrent to move forward on the theoretical knowledge beyond the objects of experience, as it is defined in its concepts and principles under the notion of ontology, the critique of pure reason sets the stage to advance the possibility of a knowledge with the mere principles of pure reason, which is being called here as metaphysics. In this sense, Kant is conclusive: the results of a critique of pure reason would allow us to state that the "amplitude of theoretical knowledge of pure reason does not extend beyond the objects of the sensibility" (Kant, Ak XX, 273) "no knowledge of the supersensible is possible with regard to the speculative capacity of reason" (Kant, Ak $X X, 277)$. "For the ultimate purpose of metaphysics, as it is an attempt to transcend the sensible and move on to the supersensible, this knowledge is, therefore, inappropriate" (Kant, Ak XX, 286). The restriction in the advance of knowledge by reason is given by the way Kant grants 
objective reality to the categories. Kant mentions two procedures with respect to the categories of the understanding and the ideas of reason: the scheme and the symbol (Kant, Ak XX, 279-280). These two procedures provide referential rules (semantic ones) to the objectification of the categories used in the formulation of the knowledge stated in judgments. If the referential rules are restrictive as for the use of the categories and limit what can be considered a valid theoretical knowledge, then we shall ask along with Kant: "What kind of progress can metaphysics make on the supersensible?" (Kant, Ak XX, 296). Kant will reserve the term "supersensible" to refer to the territory of freedom. It would go from philosophy as speculative science to philosophy as doctrine of wisdom (Kant, Ak XX, 301). The performed transition is from the theoretical reason, which tries to report on the cognitive experience and its limits, to the practical reason, which tries to report on the practical experience (or moral experience in a broad sense) which is already pure, that is, only on principles of reason. Therefore we do not go from a physical knowledge of objects to a metaphysical knowledge of transcendent entities but from a domain of objects given to the sensibility to another domain, that of freedom. As such, Kant explains in the Introduction to the third critique the location of the concepts used in one domain and in the other one. I quote Kant:

The concepts, to the extent that they can be related to its objects and regardless of whether it is possible or not to have knowledge of them, have their field (Feld), which is determined simply according to the relation its object has with our capacity of knowledge. The part of this field, wherein knowledge is possible for us, is a territory (Boden) for these concepts and for the capacity of corresponding knowledge. The part of this field to which they dictate its laws is the domain (Gebiet) (dithio) of these concepts and the capacities of knowledge that fit them (Kant, KU XVII).

So then we have the scope of the objects given through the sensibility (and here we find the ontology) and the scope of freedom and its respective concepts (what Kant is pointing out in the text Fortschritte [Progress] as metaphysics). Regarding the part concerned 
to a transcendent theology, Kant makes his position very clear with regard to a speculative on the Ens Originarium, metaphysics and the limits of ontology. I quote Kant (Ak XX, 301-304):

With metaphysics reason wants to make itself a concept of the origin of all things, of the original being (ens originarium) and of its intrinsic nature; it subjectively begins by the original concept (conceptus originarius) of thingness in general (realitas), that is, of that whose concept represents in itself a being the difference of that whose concept represents a non-being, however, in order to objectively think the unconditional of the original being, it represents this original being as if it contained the whole (omnitudo) of reality (ens realissimum), thereby determining completely its concept of supreme being, which no other concept draws, and with regard to the possibility of such being, as Leibniz adds, there is no difficulty in proving, because the realities as mere statements can not contradict themselves, and what is thinkable because of its concept does not contradict itself, that is, everything of which a concept is possible is also a possible thing, this is, none the less, something before which reason guided by the critique may well enough shake its head.

It will be good for metaphysics not to take concepts for things or even their names for concepts therefore reasoning entirely on emptiness.

According to Kant, in the dogmatic metaphysics we make a subjective condition of thought the objective condition of possibility of things themselves. Thus, we mistake concepts that may have a logical meaning with things that must be given in sensibility. Freud names this phenomenon schizophrenia. However, Kant shows that it is the procedure of a dogmatic metaphysics which has not made that fundamental distinction and tries to prove any of these two statements:

1) A perfect metaphysical being must necessarily exist, for if it did not exist it would miss perfection.

2) A being that exists as a necessary being must have got supreme perfection, for if it hadn't, it would not be a priori fully determined by its concept, therefore, it could not be conceived as necessary. 
By the logical-semantic analysis of statements, Kant comes to the conclusion that out of a supposed existence we can not affirm a necessary existence. The central issue herein will be about what existence is. While in dogmatism the existence is a predicate, in Kant the existence as a position will be propounded. The rule which enables the concept of existence to be applied to objects given in sensibility (space-time) will grant the restriction of its use and will allow the bounds of a knowledge said valid to be settled (Perez, 2008, 74 ss/ff).

This is how we understand Kant's definition of ontology in $\mathrm{KrV}$ A 247:

Its fundamental propositions are merely principles of the exposition of the phenomenon, and the snooty name of ontology, which accredits to itself the pretension to offer, in a systematic doctrine, a priori synthetic knowledge of things in themselves (eg. the principle of causality) must be replaced by most modest denomination of simple analytics of pure understanding.

Indeed, what the Transcendental Analytics offers are exposure principles of the phenomenon and not predicates of the being qua being or the thing-in-itself. Seen in these terms, Kant's referencialist mark leads us to define the critical project from a transcendental semantics. It is within this development of this transcendental semantics, out of the transcendental deduction of the categories, going through the schematism, to the principles of understanding that we shall find the "ontological" argument. In other words, the ontological matter is solved within a drawing upon the what and the how of the judgments, that is, upon what is related and how it is related in the structure of a judgment.

\section{Criticism as semantics}

The Critique of Pure Reason has been interpreted over the last two hundred years in many different ways, namely: as psychology, 
theory of knowledge or even as the groundwork for metaphysics. Among all the interpreters, to name a few, we may mention from the most contemporary ones as Patricia Kitcher (1990), to the wide range of the ones called neo-Kantian as Herman Cohen (1885) or his opponents as Heidegger (1998).

However, according to Kant, a critique of pure reason should provide us the elements to recognize whether a knowledge can be said valid or not. This would allow us to decide whether the metaphysical problems of transcendent objects are able to be solved by means of theoretical reason or not. Thereupon Kant said in $\mathrm{KrV}$ B 19 that the real problem of a critique of the reason is contained within the question: how are a priori synthetic judgments possible? In other words: what are the conditions of possibility for a statement to be considered valid, that is, to be determined as true or as false? This is the starting point for understanding criticism as from the judgment's structure. We may say that this was the schedule of the interpretations on the critique over the past 50 years. Yet the problem would not be reduced only to the syntactic structure of propositions but it would be outspread to the meaning of the concepts involved in its formulation. This is something Kant himself gradually understood in the pre-critical period. It can be seen especially at the end of the text on the false subtlety of the four figures of the syllogism and in that one on the only possible argument for the existence of God (Perez, 2008; Valentim, 2009). Thus, among those who consider the structure of the judgment as the fundamental element and the starting point we can find a subgroup that highlighted the semantic element.

Rudolf Zocher (1959, 138 e ss./ff.) in Kant Grundlehere. Ihr Sinn, ihre Problematik, ihre Aktualität states that there is an update of the Kantian doctrine of transcendentality and of validity in terms of a semantics even in neokantianism and especially in Emil Lask (2003) in Die Logik der Philosophie und die Kategorienlehre (written in the early twentieth century, miding the 1911 edition). Lask sought to perform the transcendental thought under the elimination of subjectivity in the form of a pure objective semantics. On this regard Zocher alleged: 
"No doubt there are principles in Kant's doctrine for a pure objective semantics" (Zocher 1959, 143).

Butts, R. (1969) in Kant's schemata as semantical rules; Sellars, W. (1968) Science and Metaphysics: Variations on Kantian Themes and Hintikka (1973) Logic, Language-games, and Information: Kantian Themes in the Philosophy of Logic are work cases where the semantic matter is mentioned.

Wolfram Hogrebe (1974) in Kant und das Problem einer transzendentalen Semantik situated the central problem of Kant's doctrine as the issue of meaning (Bedeutung). In order to develop his thesis he begins by examining the multiple signification of the word "Konstitution" both in its non-philosophical and philosophical meanings up to the idea of "Wortgebrauchs" in Carnap, the analytic tradition and Kant. With these elements and with the analysis of a part of the Critique of Pure Reason, especially the transcendental schematism, he propones a transcendental semantics in Kant.

After Hogrebe, there is the work of Brittan (1978) in Kant's Theory of Science with another mention of Kant's semantical problem.

Zeljko Loparic's semantic interpretation developed in his doctoral thesis (1981) and published as a book (2000) under the title $A$ semântica transcendental de Kant offers us new elements. The difference among Lask's texts (2003), in which we find the beginning of a theory of the concept in Kant, Zocher (1959), in which we can read a mention of the possibility of a semantics in Kant, and Hogrebe (1974), in which a transcendental semantics as of an analysis and interpretation of the schematism inserted into the tradition of the problem of the use of the concept is formulated, Loparic's thesis presents an exhaustive analysis of the entire structure of the first critique which allows us a systematic reading of the work wherein all of its elements contribute. The critique understood as a theory of resolution of the problems of reason and the transcendental semantics as its center allow us to respond to the issue unfolded by the skeptics against the dogmatics concerning the validity of the theoretical objective knowledge, not in order to propone a "new metaphysics" but to propound a query upon the conditions of possibility (validity) of the propositions in a cognitive experience. 
There are other works in line with a semantical interpretation or that mention the problem carried out after Loparic's. For instance, Brandt (1995) The table of judgments: Critique of pure reason A 67-76; B 92101; McDowell (1994) Mind and World; Robert Hanna's (2001) Kant and the Foundations of Analytic Philosophy and A.B. Dickerson's (2003) Kant on representation and objectivity. I will restrict myself to the fundamental structure of all the thesis expounded by the semantic interpretation of Campinas during the years 1980, 1990 and 20007.

\section{The semantic project and the kinds of judgments}

According to Kant, the metaphysical problems are not merely idle or dispensable for they are produced by the very operation of reason. In this sense, they must be considered as being determined as possible to be resolved or not. I quote Kant (KrV A VII)

Human reason, in a certain field of its knowledge, has the singular fate to find itself plagued by questions that cannot be avoided, for they are imposed by its nature, but to which it can neither answer for they quite overcome its possibilities.

It is just because the problem is formulated in the very operation of reason that Kant seeks a solution inquiring as such. In order to decide on the matter, Kant queries for the conditions of possibility of $a$ priori synthetic propositions. I quote Kant (KrV B19)

Nevertheless the real problem of pure reason is within the question: How are a priori synthetic judgments possible?

The fact that metaphysics has remained in so vacillating state of uncertainty and contradiction until today is simply due to not having

7 There is a series of papers published by many researchers within the semantic interpretation in the form of articles, dissertations and theses. I will cite here as an indication the ones published in Faggion, A \& Beckenkamp, J. (2013) Temas semânticos em Kant. Sao Paulo: DWW Editorial. The term "semantic school of Campinas" was formulated by Ricardo Terra in (2012) História e Direito em 1784. Comentários sobre a interpretação da "Escola Semântica de Campinas". Studia Kantina 12: 175-194. 
thought this problem over sooner, perhaps not even the distinction between analytic judgments and synthetic judgments. The redemption or the downfall of metaphysics is based on the solution of this problem or on a satisfactory demonstration that there really is no possibility to resolve what it seeks to see enlightened.

The procedure of analysis and synthesis used by Kant in the presentation of his investigation allows us to find the ingredients or elements of judgment and get to a result. This gives us, as conditions of possibility of the judgment, sensible representations, intellectual representations, syntactic rules of the relation among concepts, semantic or reference rules that link concepts to intuitive multiple, operative rules of the function of reason in a broad sense which enables to perform the device that carries out the syntactic and semantic rules, and the operator of the rules which Kant calls human nature or also human reason.

Thereat we are in a position to move from the natural disposition to the decision upon the metaphysics as a science. I quote Kant $(\mathrm{KrV}$ B22):

Thus, in all men and since within them reason raises to speculation, there has always been and will continue to be a metaphysics. Therefore, and also upon it, the question is made: how is metaphysics as a natural disposition possible? that is, how do the questions, which pure reason rises and that, on its own needs, is taken to resolve the best way it can, arise from the nature of human reason in general?

However, as so far all attempts to respond to these natural questions, such as, for example, whether the world has a beginning or it has been there since eternity, etc., always met with unavoidable contradictions, we can not be satisfied with the mere natural disposition of pure reason to metaphysics, that is, with the pure capacity of reason, from which, by the way, a metaphysics is always born (whatever it is); on the contrary, it has to be possible, as regards it, achieve one certainty: the knowledge or ignorance of the objects, that is, a decision as to the objects of its interrogations or as to the ability or inability of reason to formulate judgments that refer to them; consequently, to extend our pure reason confidently or to put safe and determined limits on it. This last issue, that 
comes along with the general problem outlined above, could rightly be formulated as: how is methaphysics as a science possible?

Thereby, the problem of the nature of cognitive experience's object and the ability of reason to formulate judgments referring to them is presented as the core issue formulated in the question about the possibility of judgments.

This problem is not only formulated in the first critique in 1781 and 1787. The kantian philosophy's program is expressed in the same way throughout the entire work. In Grundlegung zur Metaphysik der Sitten (GMS) 1784, referring to the problem of practical reason, Kant says: "Now the question arises: how these imperatives are possible." Kant still advances into a specification of the undertaken task. I quote (AA 04, GMS 48):

[...] the question of how the imperative of morality is possible is undoubtedly the one that needs solution, since it is by no means hypothetical and, consequently, the objectively represented necessity can not be based on any assumption as in the hypothetical imperative.

However, this task seems to be only drafted in the GMS regarding what this work states (AA 04 GMS 95):

How such a synthetic practical proposition is possible a priori and why it is necessary, that is a problem whose solution is not within the limits of Metaphysics of Morals, neither have we stated its truth here, much less have we claimed to hold in our possession a proof of the same.

But finally in AA 04, GMS 110, the question explicitly arises again, indicating right after a demonstration of "how is a categorical imperative possible?".

The explicit question about the possibility of synthetic propositions is neither limited to theoretical reason nor to practical reason. In the third critique, within the "Research on the question whether in the 
judgment of taste the feeling of pleasure precedes the judging or if this judging precedes the pleasure," Kant says: "The solution to this problem is the key to the critique of taste and hence worthy of full attention". At this point there is the following statement:

The pleasure we feel we ascribe to every other person, as if when we find something beautiful, it were a quality of the object, which would be stated in it according to concepts; for beauty by itself, without reference to the feeling of the subject, is nothing. Yet we have to lay aside the discussion of this question until we get the answer to that other one: how are aesthetic judgments possible? (AA $05 \mathrm{KU} 30$ ).

Kant's sentence is as clear as it is in the other two cases. Both in theoretical reason and practical reason as in reflective judgments, the problem is the possibility of synthetic propositions; that is, how cognitive, imperative and aesthetic a priori synthetic judments are possible.

Therewith we would already have elements to believe that the problem of pure reason in its systematic critical task, as transcendental philosophy in a broad sense (not just restricted to the first Critique), goes decidedly through the question about the possibility of judgments. However, the different moments of Kant's text in which the task appears explicitly do not end there. In Die Religion Innerbalb der Grenzen der blossen Vernunft (RGV), we can mention a very enlightening footnote:

If the proposition 'There is a God', therefore: 'There is a supreme good in the world', has (as a proposition of faith) to come only from moral, it is an a priori synthetic proposition; although it is accepted only on practical reference, it goes beyond the concept of duty, that moral holds (and that does not presuppose any matter of will, but only its formal laws), and therefore can not be developed as from moral. But how is such an a priori proposition possible?

\section{Kant continues:}

The consonance with the simple idea of a moral lawgiver of all men is, of course, identical to the moral concept of duty in general and thus the 
proposition that commands such a consonance would be analytical. But the acceptance of the existence of an object says more than its mere possibility. The key to solving this problem, as far as I believe to discern it, I can only indicate here, without explicating it. (AA 08, RGV BA IX - X)

In this line of thought, we may think that the Kantian question on the possibility of propositions is extended to the doctrine of right with the statement: "This is mine." I quote Kant in paragraph 6 Deduction of the conception of purely juridical possession of an external object (possessio noumenon):

The question "How external mine and yours are possible" is resolved within the question "How is a purely juridical (intelligible) ownership possible?", and this one, for its turn, in the third one: "How is an a priori synthetic juridical proposition possible?"

We can also find the same concern about history in the text: Der Streit der Fakultäten, where Kant must decide on the validity of the proposition "The human race progresses toward the better." It is an a priori synthetic proposition and therefore its validity can not be decided neither only by the law of identity and non-contradiction nor empirically.

In all cases we have cited here, the possibility (validity) of a priori synthetic propositions is resolved as to not only clarify the syntactic rules of its structure (Subject - logical connective - predicate: S.p) but also to introduce some sort of sensible element among its ingredients. This allows to establish some sort of reference.

In the first critique, the categories of understanding relate to intuition and thereby restrict its use to the objects given in sensibility (Loparic, 2000; Perez 2008). In the second critique, we already have a principle of pure reason and a kind of feeling that Kant calls "respect" (Achtung) (Loparic, 1999; Perez 1999, 2001, 2008). In the third critique, we find the categories linked to a feeling of pleasure and displeasure (Loparic, 2001, 2010; Perez, 2006, 2008). In the doctrine of judgment, this is mine relates to a coercive force of the Estate (Loparic, 2005). In the reflection on history, the progress toward the better of the republic's 
ideas is associated with the affection of enthusiasm (Perez, 2006, 2014) . $^{8}$ In each case (each type of judgment), we find that the intellectual representations do not stand on its validity without being related to some form of sensible element. This operation of Kant is what we call transcendental semantics.

The use of term semantics refers to the problems of meaning, signification and reference of the concepts explicitly exposed by Kant throughout his work. The problem of the meaning of concepts is not a Kant's invention. In the dialogue by Plato (2014), Cratylus, we find a reflection on the origin of language and the relation of words with what they refer to. In Aristotle's Logic (2008), not only the meaning of the word but also of the proposition is explicated. We could also say that the elaborations of apophantic logos and semantic logos refer to the question of meaning. The term semantikos that is also found in the studies of the Stoics is translated by semantics and in german by bezeichend, expression used by Kant. In Sumulae logicales by Pedro Hispano (1986), which takes up much of the scholastic tradition, we also find developments of theories of meaning, an assumption of something like an intentional and extensional semantics and also an assumption of a realistic semantics (Beuchot, 1992). In the Essay Concerning Human Understanding, Locke (2012) also approaches the problem of the meaning of words. All this is to show that it is not about a new problem discovered this century or the last one. Even Donald Davison (1985, 1999) states that the study of the general structure of language was done by Plato, Aristotle, Hume, Kant, Russell, Frege, Wittgenstein, Carnap, Quine and Strawson.

However, Kant has no theory of the origin of language as well as no general theory of meaning, only he approaches the problem of the validity of propositions regarding the signification of the concepts and thereunto uses a very specific semantics that Loparic (2000) calls Transcendental. It is about the elements and the modes of the relation of signification which allows to decide whether a particular propositional

8 Each of these cases was treated under different aspects in articles, theses and dissertations in the semantic school of Campinas. 
kind may be valid or not in a particular experience, whether cognitive, practical, aesthetic, on law or on history. It is no other things besides the question about what (was) is related and how (wie) it is related.

The old ontology as the science of being and metaphysics as the knowledge of the supersensible was replaced in Kant by the analysis of propositional kinds and the constitution of meaning fields where these propositions may come to make sense, that is, they may be said as valid or as invalid and thereat they can come to be used in the formulation of problems and eventually in their respective resolutions.

\section{Human nature and the theory of judgment}

Kant's theory of judgment starts from the structure S.p and draws a distinction, according to the general mode of validation, between analytical (whose resolution is given by the law of identity and non-contradiction) and synthetic (whose resolution is not given by the law of identity and non-contradiction and it requires another element). The latter one is divided into a posteriori and a priori regarding the experience. The transcendental semantics refers to what and how on these last propositions. In turn, the a priori synthetic propositions are divided into different kinds according to the type of experience one needs to approach (cognitive, practical, aesthetic ...).

Nevertheless, Kant's task does not end here but it still consists of building the apparatus that runs the rules in each case. The operator or executant of the rules is called by Kant as subject, man (in a generic sense), human nature, mankind, humanity, people or community according to the propositional kind and the experience in question. The subject of the cognitive experience must have concepts, logical operators and also perceptions (first critique), but it does not need to have a sense of respect, this is essential in the moral experience (second critique). Similarly, the aesthetic experience requires a sense of pleasure and displeasure (third critique), but the affection of enthusiasm is indispensable in the sublime judgment and in history (third critique and 
the second part of the Conflict of Faculties). In each case, the specific sensibility corresponds to the kind of judgment in each experience.

We could also say that the work procedure we perform as from Kant is noticed in the following steps: 1 . set the kind of the fundamental proposition stated in the experience in question, 2. find its components, 3. enunciate its syntactic rules, 4 . enunciate its referential rules, 5 . enunciate its operators and 6 . build the executant of the rules and logic operators that formulates the statement within a field of meaning. Not only it is not about accomplishing the totality of being yet neither it is about erecting a unifying subject. Although we can say it is about the same reason, its functioning, the operating elements and the operator itself change.

With this procedure, not only do we grant systematic unity for the reading of transcendental philosophy - showing that it is not sometimes theory of knowledge, sometimes moral, sometimes art, sometimes biology, but it is about the possibility of synthetic judgments - as well as we are able to go beyond the experiences and kinds of judgments formulated by Kant and comprehend transcendental semantics as a philosophical labor. Thus, the work program can proceed: 1. Within the very work of Kant; 2 . In reading of the history of philosophy; 3 . Approaching the conditions of possibility of other experiences.

\section{The work program within Kant's own work}

In 1982, Zeljko Loparic, before the examination table of the faculty of philosophy and letters at the Catholic University of Louvain, defended his doctoral thesis entitled Scientific solving-problem ina Kant and Mach and which he had been working on since 1978. The thesis of the work sees the Critique of Pure Reason as a theory of resolution of unavoidable problems of reason and, thereby, Kant's metaphysics of nature is a scientific research program within the field of nature. To this end, Loparic propounds that the method used by Kant is the analysis and synthesis from the greek geometers and that reason is a problem-solving human apparatus with sensible and intelectual operations and representations. He also propounds 
that the transcendental analytic is to be interpreted as transcendental semantics, that is, an a priori theory of reference and truth that would ground Kant's theory of resolution of problems. Thus, the metaphysics of nature, as an a priori scientific research program, has a first level based on the canon of the power of judgment doctrine and a second level based on heuristic or regulative canon of speculative reason. In tis sense, a dynamic theory of matter as an a priori research program for the rational mechanics is developed. The doctoral work has a second part dedicated to Mach's concept of science and establishes a relation with Kant. Regarding the first part, since 1982 a series of studies on specific themes and issues has been published in the form of articles and book chapters with the consequences of this thesis, in the same way, others have proceeded on different topics and presented their findings in the form of dissertations, theses and articles. Thereby, a significant number of researchers has developed dissertations and theses advancing at different points in the semantic interpretation during the decades of 1990 and 2000. Suze Piza, Olavo Pimenta, Marcos Alberto Oliveira, Agostinho Meirelles, Orlando Linhares, Alexandre Hahn, Claudio Sipert, Andrea Faggion, Joãonzinho Beckenkamp, Fábio Scherer, among others (including myself), worked on the line started by Loparic in Campinas ${ }^{9}$. Currently, there are several theses been written at

9 Regarding dissertations originated out of the transcendental semantics in the first critique and its consequences on the entire transcendental philosophy advised by Zeljko Loparic himself we shall highlight: Marco Antonio Frangiotti. Kant e a análise geométrica grega. 1989; Silvio Pinto. Uma reconstrução lógica da segunda antinomia da razão pura. 1991; Daniel Omar Perez. Significação dos conceitos e solubilidade dos problemas. 1996; Marcos Alberto de Oliveira. Razão problematizante e investigação científica na filosofia kantiana da natureza. 2000; Agostinho de Freitas Meirelles. História e objetividade em Kant. 2002; Olavo Calabria Pimenta. Elementos fundamentais da analítica transcendental de Kant. 2003; Andréa Luisa Bucchile Faggion. O papel do facto da razão na fundamentação da moralidade em Kant. 2003; Cesar Tadeu Fontoura. Aspectos semânticos da exposição transcendental do juízo de gosto. Estudo sobre a estética kantiana na Crítica da faculdade do juízo. 2004; Alexandre Hahn. Problemas semânticos na doutrina da virtude de Kant. 2005; Fábio César Scherer. Intuição e dedução nas regras para a direção do espírito. 2005; Juliano César de Lazari. 0 método combinado de análise e síntese em Kant. 2006; Chelaine da Silva. Faktum der Vernunft: considerações sobre suas interpretações. 2006; Cláudio Sipert. O problema da realidade objetiva da idéia do sumo bem em Kant. 2008; Ricardo Machado Santos. Moralidade e história na Idéia de uma história universal de um ponto de vista cosmopolita de Kant. 2010; Fabiano Queiroz da Silva. A liberdade prática na Crítica da razão de Kant: 0 problema da compatibilidade entre a solução crítica da terceira antinomia e o Cânone. 2010; Rodrigo Augusto Rosa. Sistemas teóricos em Kant: 0 controle da experiência mediante as máximas da razão. 2011; Ricardo Machado Santos. Moralidade e História na Ideia de uma história universal de um ponto de vista cosmopolita de Kant; 2011; Diego Frederichi. Posse Jurídica e Estado na Doutrina do Direito de Kant. 2014. Regarding doctoral theses supervised by Loparic, we shall highlight: Leopoldo Fulgencio. 0 método especulativo em Freud. 2001. Daniel Omar Perez. Kant e o problema da significação. 2002. Fábio César

Rev. Filos., Aurora, Curitiba, v. 28, n. 44, p. 459-488, maio/ago. 2016 
different postgraduate programs in Brazil which work, dialogue or reject the semantic interpretation. Along this period, it was also realized that the work held in the first critique could be explicated in the second one upon practical propositions, further upon reflective propositions, law, history, pedagogy, politics, virtue and so on.

Thus, we shall keep on progressing in order to elucidate the problem of the different kinds of judgments and the objects of different domains as well as the construction of different operators inquiring into the published texts, lessons, reflections and letters.

\section{Subsequent results of Kant's project}

In the nineteenth century, german idealism as from Fichte, Schelling, Schopenhauer and Hegel had propounded a philosophy after Kant and under great criticism against him. They attacked his lack of ultimate unity, the negative on accessing the thing-in-itself ${ }^{10}$, which they considered logicism or formalism and characterized

Scherer. Teoria kantiana dos juizos jurídico-políticos a priori segundo o método de análise e síntese. 2005. Alexandre Hahn. A função da antropologia moral na filosofia prática de Kant. 2005. Marcos Alberto de Oliveira. A idéia de uma doutrina da virtude na metafísica kantiana dos costumes. 2005. Orlando Bruno Linhares. A gênese das antinomias matemáticas kantianas. 2005. Andrea Luisa Bucchile Faggion. Dedução transcendental e esquematismo transcendental. 2007. Alexandre Hahn. A função da antropologia moral na filosofia prática de Kant. 2009. Agostinho de Freitas Meirelles. Crítica e história na filosofia de Kant. 2009. Fábio César Scherer. Teoria kantiana dos juizos jurídico-políticos a priori segundo o método de análise e síntese. 2010. Cláudio Sipert A modificação de sentido do sumo bem na filosofia tardia de Kant 2013. Suze de Oliviera Piza. Semântica transcendental e semântica histórica. 2014. Ricardo Machado Santos. Sobre os fins da razão: Auto-formação e perfeição moral do homem no pensamento tardio de Kant, 2015. Rodrigo Augusto Rosa A Synthesis Speciosa como uma abordagem modeloteorética das ciências exatas em Kant, 2015. These productions unfold in other researches advised by other researchers in postgraduate courses in other Brazilian universities, especially at the Universidade Federal de Londrina and the Pontifícia Universidade do Paraná.

${ }_{10}$ In Juan Adolfo Bonaccini (2000) A dialética em Kant e Hegel. Ensaio sobre o problema da relação entre ser e pensar. Natal: Editora da UFNR, we find an excellent study upon the ideas and the antinomies in Kant, upon the question on the absolute in Hegel and upon how the critique from Hegel to Kant on the issue of antinomies is presented. Em Juan Adolfo Bonaccini (2003) Kant e o problema da coisa em si no idealismo alemão. Rio de Janeiro: Relume Dumará, we find the reconstruction of the question upon the thing-in-itself in Kant and his contemporaneity. The study includes a review of Reinhold, Jacobi, Maimon, Schulze, Beck, Fichte, Schelling and Hegel, besides the approach to the twentieth century's interpretations of the problem, such as: Prauss, Buchdahl and Allison. Both works by Bonaccini (2000 and 2003) are the starting point for an understanding of the project change on the problem approached by Kant. 
his work at various times as psychology. Certainly, it is neither an overcoming of the kantism nor a deepening, but a change of project. Indeed, german idealism comes to be another philosophical project - a project that sets out its statements as from the absolute and it is from this impossible place that it also sets out the criticisms against Kant. Therefore, we go from the question about the conditions of possibility of synthetic propositions on a particular experience (cognitive, moral, aesthetic etc.) to the perspective of the whole. In this way, we return to the assertion of what can not be sustained, according to the critical philosophy. Resuming german idealism projects from its basis means a way of affirming the metaphysical procedure that Kant had criticized since 1781. However, while reviving the problem of the unity of the system and the problem of access to the thing-in-itself, such idealistic reflections are the basis for subsequent attempts of an ontological thought, especially with regard to new self-proclaimed realistic attempts in all its modalities.

In the twentieth century, there are several philosophical projects that resumed the question on metaphysics and ontology and which can be divided into four main lines of research: 1. phenomenology; 2. analytic philosophy; 3 . marxism; 4. post-structuralism. Phenomenology starts out of Husserl's critique against Descartes and Kant and opens a new research field later developed by Heidegger, Sartre, Merleau Ponty and current phenomenologists. Analytic philosophy, regarding ontology, starts out from Russell and Carnap and progresses with Quine; currently it is held by Searle and logical semanticists. In this line, Kant was criticized on the notion of experience and the validity of his invention of "a priori synthetic judgments". Marxism developed an ontology with Lukács, another with Adorno and, nowadays, another with Badiou, much away from Kant. Deleuze's and Derrida's post-structuralism, in several different ways, propounds another kind of debate on ontology and metaphysics. Anyway, in all cases we find criticism against Kant as a decisive element of its philosophical work. In general, from all the four lines, the critiques are against his lack of 
introduction of historical time, the notion of experience, the invention of synthetic judgments or the formulation of the transcendental subject.

A preliminary diagnosis shows us that in a broad aspect it was not possible to do philosophy and resume the problem of metaphysics and ontology without establishing a relation with Kant's work. Given the ample horizon of the debate, I will indicate only four works published in the twenty-first century (according to the lines indicated above) on ontology and metaphysics, which proposes a thought on the issue after Kant: 1. Quentin Meillassoux (2008) After Finitude: An Essay On The Necessity Of Contingency; 2. Markus Gabriel (2011) Transcendental Ontology: Essays in German Idealism; 3. Timothy Williamson (2013) Modal Logic as Metaphysics; 4. Renuad Barbaras (2013) Dinamique de la Manifestacion. Meillassoux seeks a speculative realism resuming his inheritance in relation to Alain Badiou. He discusses the question of the subject and the meaning of propositions as from Descartes and against Kant. Gabriel seeks to explain the being also as from the absolute, since the tradition started by Schelling, and questions the kantian investigation on the conditions of possibility claiming a realism. Williamson is inscribed in the analytic tradition in dialogue with Kripke and Russell, working the meaning of propositions in the course of semantics. Finally, Barbaras brings up Husserl's phenomenology rethinking the conditions of the experience.

We understand that within this horizon of proposals and discussions it is possible to resume transcendental philosophy with regard to what we see as reality and the behave in relation to it and in it. I think it is possible in each case to give an answer as from the very work of Kant. The result of the resume of Kant's work to answer contemporary ontological formulations is what we will call a semantic neokantianism. The procedure to be retaken is the question about the conditions of possibility of an experience as from the question about the condition of possibility of the statement. The beginning of the task is guided by the enunciation point of the statement in question to which we must return in order to elucidate and determine the starting point itself. This is how we understand the kantian route that goes from the question 
on the possibility of synthetic propositions to the development of an anthropology from a pragmatic point of view as a science.

In recent years, in the scope of analytic philosophy, a large amount of works on semantics and pragmatics that allow us to advance ontological and metaphysical issues with new tools have been developed, some of them not only consider the structure of the statements in the speech but also the subject of enunciation. Within phenomenology, progress was made on the concept of experience in relation to a self or to the subject of that experience. Either one element or the other (semantic and pragmatic elements and the notion of experience) may be considered useful to advance the idea of a semantic as philosophy.

We also believe that as of the transcendental semantics work procedure it is possible to rebuild a reading in the history of philosophy as from its problems, resolution modes and validation of these resolution modes. We understand that Lucas Angioni's interpretation on the work of Aristotle draws nearer this type of approach. Likewise McDougal's reading on Hegel emphasizes the semantic element. Sonia Barreto and Suze Piza essayed transcendental semantics and existential semantics on one case and historical semantics on another case in the reading of Heidegger and Foucault respectively in their different doctoral theses at Unicamp. As well as Patricia Kauark proposes a semantics and pragmatics to meet the conditions of possibility of the quest upon semantic fields in quantum mechanics. Robert Hanna explicitly claims a contemporary neokantianism.

\section{References}

ARISTÓTELES. Tratados de lógica. México: Editorial Porrúa, 2008.

BARBARAS, R. Dinamique de la manifestacion, Paris: Vrin, 2013.

BEUCHOT, M. La filosofía del lenguaje en la Edad Media, México: UNAM, 1992.

BONACCINI, J. A. A dialética em Kant e Hegel. Ensaio sobre o problema da relação entre ser e pensar. Natal: Editora da UFNR, 2000. 
BONACCINI, J. A. Kant e o problema da coisa em si no idealismo alemão. Rio de Janeiro: Relume Dumará, 2003.

BRANDT, R. The table of judgments: Critique of puere reason A 67-76; B 92-101. Atascadero, California: Ridgeview, 1995.

BRITTAN, G. Kant's Theory of Science. Princeton: Princeton University Press, 1978.

BUTTS, R. Kant's schemata as semantical rules, IN Beck, L.W. (Ed) Kant Studies Today. La Salle, Illinois: Open Court, 1969. p. 290-300.

CAIMI, M. La metafísica de Kant. Reconstrucción de la argumentación del escrito de Kant "Los progresos de la metafísica desde la época de Leibniz y de Wolff". Buenos Aires: Editora Eudeba, 1989.

COHEN, H. Kant's Theorie der Erfahrung. Berlin: Harrwitz und Gossmann, 1885.

DAVAL, R. La métaphysique de Kant. Perspectives sur la métaphysique de Kan d'après la théorie du schématisme. Paris: Presses Universitaries de France, 1951.

DAVISON, D. Inquiries into truth and interpretation. Oxford: Clarendon Press, 1985.

DICKERSON, A. B. Kant on representation and objectivity. Cambridge: Cambridge University Press, 2003.

DUQUE, F. Estudio Preliminar. In Kant, I. Los progresos de la metafísica desde Leibniz y Wolff. Madrid: Editorial Tecnos, 1987.

FAGGION, A; BECKENKAMP, J. Temas semânticos em Kant. São Paulo: DWW Editorial, 2013.

FREULER, L. Kant et la pétaphysique spéculative. Paris: Vrin, 1992.

GABRIEL, M. Transcendental Ontology: Essays in German Idealism. LondonNew York: Continuum, 2011. 
HANNA, R. Kant and the Foundations of Analytic Philosophy. Oxford: Clarendon Press, 2001.

HEIDEGGER, M. Kant und das Problem der Metaphysik. Frankfurt am Main: Klostermann, 1998.

HINTIKKA. Logic, Language-games, and Information: Kantian Themes in the Philosophy of Logic. Oxford: Oxford University Press, 1973.

HISPANO, P. Tratados, llamados después súmulas de lógica. Trad. M. Beuchot, México: UNAM, 1986.

HOGREB E, W. Kant und das Problem einer transzendentalen Semantik. München/ Freiburg: Verlag Karl Alber GmbH, 1974.

KANT, I. Kant's gesammelte Schriften. Berlin: Walter de Gruyter \& Co, 1901.

KANT, I. Sueños de un visionario explicados por los sueños de la metafísica. Madrid: Alianza Editorial, 1987.

KANT, I. Sueños de un visionario explicados por los sueños de la metafísica. Buenos Aires: Leviatán, 2004.

KANT, I. El conflito de las facultades. Buenos Aires: Editorial Losada, 2004.

KANT, I. Los progresos de la metafísica desde Leibniz y Wolff. Madrid: Editorial Tecnos, 1987.

KANT, I. Crítica da razão pura. Lisboa: Fundação Caloute Gubenkian, 1994.

KANT, I. Fundamentação da metafísica dos costumes.São Paulo: Barcarolla/Discurso Editorial, 2009.

KANT, I. Metafísica dos costumes. Petrópolis: Vozes, 2013.

KITCHER, P. Kant's Transcendental psychology. New York: Oxford University Press, 1990.

LASK, E. Die Logik der Philosophie und die Kategorienlehre. Jena: Scheglmann, 2003. 
LAYWINE, A. Kant's early metaphysics and the origins of the critical philosophy. Volume 3 NAKS. California: Ridgeview Publishing Company, 1993.

LOCKE, J. Ensaio sobre o entendimento humano. São Paulo: Martins Fontes, 2012. LOPARIC, Z. O fato da razão: uma interpretação semantic, Analytica. v. 4, n. 1 p. 13-55, 1999.

LOPARIC, Z. A semântica transcendental de Kant. Campinas: CLE, 2000.

LOPARIC, Z. Acerca da sintaxe e da semântica dos juízos estéticos. Studia Kantiana, v. 3, n. 1, p. 49-90, 2001.

LOPARIC, Z. O problema fundamental da semântica jurídica de Kant. In: Perez, Daniel Omar. (Org.). Kant no Brasil. 1ed. São Paulo: Editora Escuta, v. 1, p. 273-313, 2005.

LOPARIC, Z. Os juízos de gosto sobre a arte na terceira Crítica. Kant e-Prints (Online), v. 5, p. 119-141, 2010.

MCDOWELL. Mind and World. Cambridge: Harvard University Press, 1994.

MEILLASSOUX, Q. After Finitude: an essay on the necessity of contingency, trans. Ray Brassier.London: Continuum, 2008.

PEREZ, D. O. Sentido e Moral Kantiana a partir de sua Estrutura Argumentativa. Anais de Filosofia (UFSJ), São João Del Rey - MG, v. 06, p. 89-96, 1999.

PEREZ, D. O. O sentimento moral em Kant. Tempo da Ciência (UNIOESTE), Unioeste, v. 8, n.15, 2001.

PEREZ, D. O. Kant no Brasil. 1 ed. São Paulo: Editora Escuta, 2005.

PEREZ, D. O. O sentido das proposições reflexivas. Crítica (UEL), v. 11, p. 35-96, 2006.

PEREZ, D. O. Os significados da história em Kant. Philosophica (Lisboa), v. 28, p. 67-107, 2006.

PEREZ, D. O. Kant e o problema da significação. Curitiba: Champagnat, 2008. 
PEREZ, D. O. A loucura como questão Semântica: Uma Interpretação Kantiana. Trans/Form/Ação, São Paulo, v. 32, n. 1, 95-117, 2009.

PEREZ, D. O. História e teleologia na filosofia kantiana. Resposta às críticas de Ricardo Terra contra a Escola semântica de Campinas. Studia Kantiana (Rio de Janeiro), v. 16, p. 144-159. (2014)

PLAT ÃO. Crátilo. São Paulo: Paulus, 2014.

SELLARS, W. Science and Metaphysics: variations on Kantian themes. London: Routledge \& Kegan Paul, 1968.

TERRA, R. R. História e Direito em 1784. Comentários sobre a interpretação da "Escola Semântica de Campinas". Studia Kantiana. v. 12, p. 175-194, 2012.

VALENTIM, M. A. Sobre a concepção kantiana de existência: a filosofia transcendental como niilismo. Studia Kantiana. v. 9, p. 201-226, 2009.

WILliAMSON T. Modal logic as metaphysics. Oxford: Oxford University Press, 2013.

WOLfF, C. Erste Philosophie oder Ontologie. Hamburg: Felix Meiner Verlag, 2005.

ZOCHER, R. Kants Grundlehere. Ihr Sinn, ihre Problematik, ihre Aktualität. Erlangen: Universitätsbibliothek Erlangen, 1959.

Received: 03/21/2016

Recebido: 21/03/2016

Approved: 06/08/2016

Aprovado: 08/06/2016 